\title{
Developing an Adaptable Web-Based Profile Record Management System for Construction Firms
}

\author{
Adedeji Afolabi, Yewande Abraham, Rapheal Ojelabi, and Etuk Hephzibah
}

\begin{abstract}
One of the administrative roles of the human resource unit is concerned with employee records management. However, an inadequate profile record system of construction workers can adversely affect the construction worker, firm, and project in planning, auditing, welfare, and so on. Therefore, the study was aimed at developing a Web-based profile record management system that can be adapted for personal use by construction firms. A use case diagram and an activity block diagram helped to understand the users' capabilities and functionalities of the Web-based profile record management system. In addition, using different user interface and a database system including a programming language to connect them, the study developed Web-based profile record management system for construction firms using the model view controller (MVC) model. The MVC model comprised of using MySQL, HTML, and PHP, respectively, in the design. Data was inputted into the Web-based profile record management system while results were presented using screenshots of the Web-based platform. In conclusion, any construction firm can register on the platform and make use of the Web-based profile record management system in order to improve record keeping attributes of construction workers' profile and enhance the construction operations of construction firms in Nigeria.
\end{abstract}

Keywords Adaptable $\cdot$ Construction industry $\cdot$ Human resource $\cdot$ Record management system $\cdot$ Web-based system

\section{Introduction}

The Nigerian construction industry is one of the largest employers of labor for carrying out its numerous human activities to deliver the necessary housing and urban

\footnotetext{
A. Afolabi $(\varangle) \cdot$ R. Ojelabi · E. Hephzibah

Covenant University, Ota, Nigeria

e-mail: adedeji.afolabi@ covenantuniversity.edu.ng

Y. Abraham

Rochester Institute of Technology, Rochester, NY, USA
} 